\title{
"A crise financeira internacional: origens, desdobramentos e perspectivas", organizado por Fernando Ferrari Filho e Luiz Fernando de Paula
}

\author{
Resenha de \\ Flávio Vilela Vieira*
}

O livro A crise financeira internacional: origens, desdobramentos e perspectivas, organizado por Fernando Ferrari Filho e Luiz Fernando de Paula, é uma obra de grande relevância acadêmica e para o debate econômico, dado que sistematiza um amplo conjunto de análises sobre a crise financeira internacional. A obra fornece ao leitor a possibilidade de assimilar o conteúdo dos diversos tópicos abordados de forma, ao mesmo tempo, concisa, através de artigos enxutos que focam suas análises nos pontos essenciais a serem discutidos, mas também envolvendo uma ampla gama de tópicos sobre os diferentes temas que permeiam um entendimento do fenômeno da crise financeira em suas diversas dimensões e canais de transmissão. O livro é composto por 34 capítulos mais uma introdução e deriva da elaboração dos dossiês sobre a crise financeira da Associação Keynesiana Brasileira.

Esta resenha tem por objetivo sistematizar algumas das principais lições e contribuições presentes na obra, sem a pretensão de exauri-las, dado que isso só será alcançado através da leitura da obra em sua totalidade.

A obra encontra-se dividida em três partes. A primeira parte é dedicada ao entendimento da crise financeira internacional, sendo analisados aspectos como as origens da crise financeira (mercado subprime), a recuperação da confiança, as consequências e as necessidades de se evitar uma possível deflação de preços, a contribuição de Minsky para se entender as características de uma crise financeira, os desafios para a nova arquitetura financeira internacional, a importância da regulação bancária, o papel dos derivativos, os impactos da crise financeira sobre as economias da Zona do Euro, entre outros. A segunda parte é dedicada a analisar os desdobramentos e caminhos para a superação da crise financeira, com destaque para a discussão da crise das finanças desregulamentadas, a regulação das instituições financeiras e o papel dos bancos nesse contexto de crise. Finalmente, a terceira parte tem como foco a economia brasileira e as respostas de política

Phd em Economia pela University of New Hampshire e pós-doutor em Economia pela University of Glasgow. Pesquisador CNPq e Fapemig. Professor associado do Instituto de Economia da Universidade Federal de Uberlândia (UFU).Email: flaviovieira@ufu.br 
econômica, e são examinados elementos tais como a crise financeira brasileira e o conceito de fragilidade financeira, a natureza da crise brasileira, o comportamento da taxa de câmbio no contexto de crise financeira internacional, o efeito contágio sobre as economias emergentes, o papel dos bancos públicos, o papel dos controles de capitais, alternativas de política econômica para se prevenir das crises, entre outros.

O livro tem ainda o mérito de reunir um amplo conjunto de economistas keynesianos que, mesmo com formações acadêmicas distintas, têm como elemento unificador uma concepção específica de quais são os elementos cruciais e definidores do funcionamento de uma economia capitalista. Dentro desse contexto, a ocorrência de crises financeiras é considerada algo intrínseco, e cujo entendimento passa por questões-chave, como o papel do Estado e os limites dos princípios de eficiência dos mercados, a regulação do sistema financeiro, a instabilidade financeira e o caráter específico das diferentes economias.

Um dos elementos de destaque das análises está associado ao argumento de que a crise financeira que se inicia em 2007-2008 deve ser considerada como um divisor de águas no sentido de questionar as virtudes do processo de globalização e desregulamentação do sistema financeiro. A percepção até então, e de forma expressiva entre as diversas correntes do pensamento econômico, considera esse processo como algo promissor e com benefícios inequívocos para as diversas economias, sejam elas em desenvolvimento/emergentes ou desenvolvidas. Além disso, está presente o argumento de que a ocorrência da crise financeira é algo intrínseco ao modus operandi dos mercados financeiros, ainda mais quando se tem como pano de fundo o processo de globalização e desregulamentação financeira com os quais lidaram as diferentes economias ao longo das últimas décadas.

Uma lição adicional assimilada com a leitura dos diversos trabalhos do livro é que a crise financeira tem um caráter heterogêneo quando se analisam os canais de impacto sobre as diversas economias, as medidas de política econômica adotadas e seus objetivos, o comportamento díspar das variáveis macroeconômicas (taxa de câmbio, gastos públicos, dívida pública, taxa de juros, taxa de crescimento, entre outros). Em última instância, cada uma dessas economias possuem especificidades que devem ser consideradas caso o objetivo seja um amplo entendimento da complexidade da crise financeira internacional e como essas economias lidam com sua ocorrência.

O leitor, ao final da leitura da obra, estará apto a distinguir os diferentes detalhes sobre como e por que a crise financeira do novo século ocorreu, quais os equívocos a ela associados e o que pode ser feito para sua superação, ainda que os custos sejam inevitáveis, mesmo que heterogêneos entre as economias mundiais. Nesse sentido, há uma clara contribuição da obra tanto no âmbito acadêmico como para o debate que a este se extrapola, o que por si só já é um mérito, sem, 
no entanto, resultar em análises sem substrato e consistências teóricas, que comprometeriam sua relevância.

O final da leitura do livro A crise financeira internacional: origens, desdobramentos e perspectivas traz consigo a certeza de que, independentemente da afinidade ou não do leitor com a análise keynesiana, seus preceitos e pilares teóricos, a obra, em seus diversos capítulos e ao analisar em detalhes as diferentes e mais relevantes nuanças subjacentes à ocorrência da crise financeira internacional, alcança seu objetivo último. Tal objetivo pode ser sintetizado como uma contribuição para o entendimento de um fenômeno, que é histórico quando se considera sua magnitude e implicações econômicas, e, ao mesmo tempo, de caráter intrínseco e recorrente, ao se considerar o funcionamento de uma economia capitalista, em que a dimensão monetária/financeira é primordial.

A recomendação não pode ser outra a não ser que o leitor interessado pelo tema tenha acesso a esta obra, pois ela certamente contribuirá não apenas para um melhor entendimento da crise financeira internacional, como também para conhecer detalhes relevantes que frequentemente passam despercebidos em análises mais específicas, focadas em um ou poucos aspectos subjacentes à ocorrência da crise financeira internacional.

\section{Referências}

FERRARI FILHO, F.; PAULA, L. F. (Org.). A crise financeira internacional: origens, desdobramentos e perspectivas. São Paulo: Unesp, 2012.

Recebido em: 10/04/2013.

Aceito em: 22/05/2013. 